Anna Suska*

\title{
The Role of the President
} of the Republic of Poland in Constitutional Crisis and Constitutional Rot

Keywords: constitutional crisis, constitutional rot, political arbitrator, the President of the Republic of Poland

Abstract: The article provides an analysis of the powers of the President of the Republic of Poland, which may have an impact on counteracting and moderating constitutional crises and constitutional rot. It aims to describe the potential actions that the head of state may take in a constitutional crisis to restore the stabilization of the state and the constitutional order with its values. The study also includes a reflection on the influence of the style of the presidency on the effectiveness of arbitration.

\section{Introduction}

Liberal democracy is not a system implemented to the state once and for all. Within it, there may be conflicts, disputes, actions carried out by people with authoritarian or totalitarian inclinations, misunderstanding of the needs of society, and gradual isolation of the authorities. The role of the constitution is to establish and maintain the foundations of the state ruled by law: principles and values, checks and balances, freedom, and human rights. A constitutional crisis arises simultaneously to the threat to the existence of any of the systemic foundations or the disturbance

* ORCID ID: https://orcid.org/0000-0003-1059-1898; Ph.D. Candidate in Political and Administrative Sciences at SGH Warsaw School of Economics. Email: a.suska137@gmail.com. 
of the harmony between them. It is what distinguishes a constitutional crisis from the controlled conflict that appears naturally in democratic states, as the system reconciles different views and the right to demonstrate them ${ }^{1}$. Democracies are more likely to be more prone to protests than autocracies. There is some research to support this proposition: in cross-country quantitative studies Edvard Glaeser and Denis DiPasquale found that dictatorships experience fewer riots than non-dictatorships ${ }^{2}$, while Paul Collier and Dominic Rohner show that democracies generally have more demonstrations, riots, and strikes than non-democracies, but wealthier democracies have fewer protests than poorer ones ${ }^{3}$. It is worth noting that conflicts, demonstrations, and riots, while not forming a constitutional crisis, may announce it.

The President of the Republic of Poland is the body that is directly obliged to ensure observance of the Constitution (art. 126 par. 2 the Constitution of the Republic of Poland). The "observance" under the conditions of the Polish political system is not only related to dangerous situations but obliges the head of state to continually and actively protect the constitutional order, monitor the activities of the authorities, react to difficulties, conflicts, and violations of the Constitution, together with taking the consequences if necessary.

The article aims to describe the potential actions enabled by the Polish Constitution that the President of the Republic of Poland may take in a constitutional crisis to restore the stabilization of the state and the constitutional order with its values. The examined hypothesis assumes that the head of state's scope of constitutional powers is sufficient to properly fulfill the function of an authority supervising the observance of the Constitution, but whether the President uses them depends on many non-constitutional factors, such as the style of exercising power, political parties reliance, lack of independence in decision-making. The research applied institutional and legal analysis, microsystem analysis, and the source analysis - essentially the Polish Constitution - to fully indicate the place of the head of state in the Polish political system and describe the roles and competencies of the institution. The functional

1 See more: R. Dahrendorf, Out of Utopia: Toward a Reorientation of Sociological Analysis, «American Journal of Sociology» 1958, vol. 64, no. 2, p. 115-127; J. Mucha, Konflikt i spoteczenstwo: z problematyki konfliktu społecznego we wspótczesnych teoriach zachodnich, Warsaw 1978.

2 E. Glaeser, D. DiPasquale, The Los Angeles Riot and the Economics of Urban Unrest, «Journal of Urban Economics» 1998, vol. 43, iss. 1, pp. 52-78.

3 P. Collier, D. Rohner, Democracy, Development, and Conflict, «Journal of the European Economic Association» 2008, vol. 6, iss. 2-3, pp. 531-540. 
method, in turn, will allow for a broader look at the institution of the President of the Republic of Poland concerning other authorities and the relationship between the individual competencies of the head of state.

\section{Constitution in liberal democracy}

Constitutions play various roles in democratic countries intertwined in the practice of their functioning ${ }^{4}$. They form the grounds of a compromised system accepted by a large part of society, and their two fundamental functions can be called legal and political. The first one describes the constitution as an act of the highest statutory force, which sets the norms of behavior of all entities in the state. The second one expresses by identifying the ideas, values, and principles underlying the country and the entire structure of state power ${ }^{5}$.

Constitutional provisions should have specific dynamics that will allow them to adapt and flexibly react to changes. In principle, the constitution is a "civic shield" in the case of the degeneration of authorities, and, at the same time, a "civic catechism" - a set of principles and values that integrate nation 6 . It must take into account the axiological system accompanying society and the actual relations of forces that bind them - otherwise, it will not be a meaningful and respected law. The constitutional provisions exist on three different levels: doctrinal, normative, and social relations. Contradictions between them can lead the constitution to become a myth rather than a binding law ${ }^{7}$. The authors of the fundamental laws must, therefore, ensure that these acts guarantee the highest possible degree of inclusiveness of society beliefs, which positively influences the increase in the acceptance of the written and introduced law. Amendments to the constitution or the adoption of a new act should only take place when there is no longer a possibility to achieve the assumed goals of the state and society through the interpretation of constitutional provisions or when an evident contradiction between the content of the constitution and these goals occurs ${ }^{8}$. For this

4 L. Garlicki, Polskie prawo konstytucyjne. Zarys wyktadu, Warsaw 2011, pp. 32-37.

5 J. Kuciński, Ustrój konstytucyjny Rzeczypospolitej Polskiej, Warsaw 2015, pp. 13-16.

6 T. Słomka, A. Materska-Sosnowska, Wprowadzenie, [in:] T. Słomka, A. Materska-Sosnowska (eds.), Konstytucja Rzeczypospolitej Polskiej z 1997 r. - ciagłość $i$ zmiana, Warsaw 2012, p. 7.

7 See: G. Maranini, Il mito della Constituzione, Roma 1996; K. M. Cern, Jak rozumieć role konstytucji we wspótczesnym społeczeństwie demokratycznym?, «Studia prawno-ekonomiczne» 2016, vol. CI, pp. 23-39.

8 B. Banaszak, Prawo konstytucyjne, Warsaw 2010, p. 70. 
reason, the process of changing this legal act is subject to additional restrictions. Constitutions are supposed to survive a period longer than, for example, one government or several decades, and need to be able to adapt to crises requiring extraordinary actions, and thus create a new reality in different historical and social contexts. A constitution without this feature, interpreted only in a way that would allow for solving problems existing at the very time of its creation and adoption, would not fulfill its fundamental role in the state and could be treated in the future only in terms of a historical source. The ad hoc creation of basic laws "for difficult times" does not comply with the idea and intentions of the introduction and existence of this type of law.

Apart from being a stabilizer of the political system, and strength for the development of the state, the constitution performs a vital social function. Its provisions are the result of a compromise between various groups, and together they build an order that creates a systemic foundation accepted by society ${ }^{9}$. The constitutions define the limits of the authorities' potential operations and protect the rights and freedoms of individuals, which provides opportunities for solving problems of citizens. Ignoring the social function of the constitution by public institutions results in the state failing to fulfill its essential responsibilities and the authorities start working on the difficulties they create themselves. That is manifested in the constant improvement and reform of the law, passing acts that are unconstitutional (so require correction in the future), creating political and media disputes that are a kind of spectacle and manipulation, not real problems ${ }^{10}$.

\section{What is constitutional crisis and constitutional rot?}

The term "crisis" is "a lay term in search of a scholarly meaning" 11. Its various usage in public discourse gradually makes it meaningless and deprives it of any real analytical value. There are some scientific efforts to specify its concept, and all of them define a crisis as a turning point or decisive moment ${ }^{12}$. Charles A. McClelland argues

9 Z. Witkowski (ed.), Prawo konstytucyjne, Torun 2002, p. 44.

10 See: R. Piotrowski, Spoteczeństwo obywatelskie w świetle Traktatu z Lizbony, [in:] M. Szyszkowska, S. Maciejewski (eds.), Polska bez Polskiego Czerwonego Krzyża?!, Warsaw 2011.

11 J. A. Robinson, Crisis, [in:] D. L. Sills (ed.), International Encyclopedia of the Social Sciences, vol. 3, New York 1968, p. 510.

12 Ibidem. 
that every crisis involves instability or - at least - threats to crucial values too ${ }^{13}$.

Usually, it is the source of crisis that defines its issue and explains how it happened. Researchers distinguish two main models in clarifying crisis: "bad practice model" and "bad theory model"14. The first one identifies the cause of the crisis as inappropriate or immoral behavior of the participants in a given system or organization. It assumes that the analyzed system is institutionally well-organized, and the fundamental rules do not require any changes. In this approach, the weakest point of the system is the irresponsible behavior of individuals or whole groups who do not follow these rules. The second model identifies the causes of the crisis in the foundations of a given system and its wrong assumptions. Although honest and moral political actors and other individuals implement the established rules, they lead to chaos and breakdown.

The constitutional crisis occurs when there is a serious danger that the constitution is about to fail at its central task, which is to keep disagreements within the boundaries of ordinary politics rather than breaking into anarchy, violence, or civil war ${ }^{15}$. It is likely to be both, a symptom and a cause, of a significant political crisis. According to Keith E. Whittington, there are two types of constitutional crises: crises of constitutional operation and crises of constitutional fidelity ${ }^{16}$. Operational crises may be either practical and theoretical, and arise when there is no possibility to resolve a serious political dispute within the existing constitutional framework. A theoretical operational crisis occurs despite adherence to constitutional provisions. Every action or decision causes chaos, multiply doubts, and contradictions, so - in fact - the constitution introduces disorder rather than order. A practical crisis, in turn, arises when the authorities are unable to exercise power effectively and are incapable of making reasonable decisions due to the lack of competence, will, etc. The second type of constitutional crisis - the crisis of

13 Ch. A. McClelland, The Acute International Crisis, «World Politics» 1961, vol. 14, iss. 1, p. 189.

14 See: G. Cooper, The Origin of Financial Crises. Central Banks, Credit Bubbles and the Efficient Market Fallacy, New York 2010; M. Ratajczak, Narracje o kryzysie: przyczyny kryzysu, [in:] B. Cymbrowski, P. Tomczok (eds.), Ekonomie w literaturze $i$ kulturze, Katowice 2017, p. 134, 138; P. Skuczyński, Pojęcie kryzysu w filozofii i naukach spotecznych a kryzysy prawne, «Filozofia Publiczna i Edukacja Demokratyczna» 2018, vol. 7, iss. 1, pp. 253-254.

15 S. Levinson, J. M. Balkin, Constitutional Crises, «University of Pennsylvania Law Review» 2009, vol. 157, iss. 3, pp. 711-715.

16 K. E. Whittington, Yet Another Constitutional Crisis?, «William \& Mary Law Review» 2002, vol. 43, iss. 5, pp. 2101-2138. 
fidelity - takes place when political actors do not abide by principles and values of constitutional order and systematically stand against the letter and spirit of the constitution. A fidelity crisis may coexist with an operational one but is more difficult to identify due to politicians' extensive manipulation and reluctance to admit mistakes.

Constitutions protect the fundamental principles and values among the society that are written and turned into regulations, making them the most important in the state and thus establishing a specific constitutional order. Each violation of such an order invades a very specified social contract - the basis for the functioning of the state ${ }^{17}$. Sometimes constitutional crises are equated with what Mark Tushnet calls "constitutional hardball”. It arises when political actors bend or defy various unwritten political conventions that are generally recognized as fair play rules in politics and exercising power but are not required by law ${ }^{18}$. That most often happens in relations between the parliamentary majority and the opposition and reveals in "rejection of applications and amendments (...) without substantive justification and is based only on the strength of the majority held, arbitrary penalties for opposition parliamentarians, unjustified shortening of parliamentary procedures, preventing the opposition from working in internal organs of the parliament"19 (such as committees). "Constitutional hardball" often causes outrage, conflicts, leads to reprisals, and the system becomes simultaneously less democratic. The authorities become less responsive to the popular will and rely their actions only on the previously obtained electoral legitimacy, which is considered the right to do everything 20 .

Democratic constitutions are not created only to set the standards of legal protection and the limits of the activity of authorities. Their provisions also ensure the efficient and harmonious functioning of institutions based on the check and balance principle, which restrains particular interests and ambitions for the common good. In this case, a huge role is played by citizens' trust in the authorities and their belief that power is exercised not for the benefit of specific individuals or groups but the interest of the entire society. Constitutional rot appears "when politicians

17 A. Suska, Prezydent Rzeczypospolitej Polskiej jako organ czuwajacy nad przestrzeganiem porzadku konstytucyjnego, Torú 2019, pp. 6-8.

18 M. V. Tushnet, Constitutional Hardball, «The John Marshall Law Review» 2004, vol. 37, pp. 523-553.

19 T. Słomka, Stan demokracji konstytucyjnej $w$ Polsce na tle modelu transformacji systemowej, [in:] T. Słomka (ed.), Demokracja konstytucyjna w Polsce, Warsaw 2019, p. 36.

20 See: J. L. Talmon, The Origins of Totalitarian Democracy, London 1952. 
disregard norms of fair political competition, undermine public trust and repeatedly overreach by using constitutional hardball to rig the system in their favor and keep themselves (or their allies) in power" 21 . The result is a slow but systematic erosion of democracy and the collapse of its institutions. Political researchers distinguish four factors that may hasten constitutional rot: trust loss, polarization, increasing economic inequality, and policy disasters. They often come together and exacerbate each other. "Policy disaster" is a term coined by Stephen M. Griffin ${ }^{22}$ and means a critical failure in decision making by authorities, which leads to loss of faith in government.

It is also worth noting that one of the discursive symptoms of the constitutional crisis is the political actors' narration about an exceptional situation, which allegedly is to justify their actions, illegal decisions, and human laws violations. It is an introduction to the creation of new practices and precedents so far not existing in politics, as well as an explanation of the violation of unwritten conventions in the exercise of power.

\section{The President in Polish political system}

The model of the Polish presidency is in a certain sense unconventional due to the Polish structure of rationalized parliamentarianism ${ }^{23}$. A feature of this system's variety is an executive presidency and an independent head of the government that leads the rest of the executive power. There are some elements that strengthen the presidency (such as universal presidential election), nonetheless, they do not change the fundamental constitutional structure based on the most important mechanism of every parliamentary system. Which is the most vital feature - the head of state does not have a direct influence on the regular functioning of the government. The other crucial aspect is the presence of emergency solutions (so called "backup power"), thanks to which it is possible to increase the effectiveness of power in the case of a crisis between the parliament and the government. According to that, the President

21 J. M. Balkin, Constitutional Crisis and Constitutional Rot, «Maryland Law Review» 2017, vol. 77, iss. 1, p. 151.

22 See: S. M. Griffin, Broken Trust. Dysfunctional Government and Constitutional Reform, Lawrence 2015.

23 See: J. Szymanek, Elementy racjonalizacji w konstrukcji parlamentarnego systemu rząów: analiza rozwiazań zawartych w Konstytucji RP, [in:] T. Mołdawa, J. Szymanek, M. Mistygacz (eds.), Parlamentarny system rząów. Teoria i praktyka, Warsaw 2012, pp. 122-159. 
should be active and play the role of an arbitrator in times of social and political unrest ${ }^{24}$. It means that to fulfill his tasks properly and function beyond divisions, the head of state needs an appropriate range of constitutional powers, as well as freedom from any influences of political parties $^{25}$.

The institution of the President of the Republic of Poland is particularly essential for the uninterrupted existence of a democratic state ruled by law. The Constitutional Tribunal admitted that the President - as the supreme representative of the Republic of Poland, the body that ensures observance of the Constitution and safeguards the sovereignty and security of the State - should represent high moral qualifications: "(...) Although the Constitution does not express this requirement directly anywhere, it results both from Polish legal tradition and the intentions of the constitutional legislator. It also results indirectly from the legal requirement of moral qualifications from numerous state officials occupying much lower positions, associated with less responsibility and much narrower powers. If persons performing various public functions are required to have specific moral qualifications, it is comprehensible and expected that a person holding honorable and the most responsible position of the Head of State - the President of the Republic of Poland - has them even more" 26 . One should agree that it is therefore unacceptable for a person representing this specific institution to break the law (both in the past and during his term of office), fail to respect the principles and values of the constitutional order, and purposely create circumstances provoking chaos and conflict.

The legitimization process of the institution of the President of the Republic of Poland strengthens its the position in the whole Polish political system. Since 1990, the head of state shall be elected by the Nation in universal, equal, and direct elections, conducted by secret ballot (art. 127

24 B. Dziemidok-Olszewska, Instytucja prezydenta w panstwach Europy Środkowo-Wschodniej, Lublin 2003, p. 330.

25 This concept is to some extent inspired by the theory of constitutional monarchy by Benjamin Constant, in which royal power is a neutral power obligated to protect, balance, and restrain the excesses of the other powers (executive, legislature, and judiciary). The essential difference is that the President is a part of the executive power in Poland. See more about the theory of constitutional monarchy by Constant: K. S. Vincent, Benjamin Constant and Constitutionalism, «Historia Constitucional» 2015, no. 16, pp. 19-46; B. Constant, O monarchii konstytucyjnej i rękojmiach publicznych, Warsaw 2016, p. 78.

26 Judgment of The Constitutional Tribunal, 10 November 1998, Ref. no. K 39/97, https://sip. lex.pl/orzeczenia-i-pisma-urzedowe/orzeczenia-sadow/k-39-97-wyrok-trybunalu-konstytucyjn ego-520128297 (22.07.2021). 
of The Constitution of the Republic of Poland). Only a Polish citizen who, no later than the day of the elections, has attained 35 years of age and has a full electoral franchise in elections to the Sejm may be elected President. Before running in the election, each candidate must gather support by the signatures of at least 100,000 citizens having the right to vote in elections to the Sejm. This fact additionally emphasizes that it is not someone else, but the Nation, who is the principal of the head of state, and whose will should be followed mostly by the President while holding the office.

The legitimacy obtained in general elections is of particular importance - both political and psychological - because it links with a stronger mandate, which makes the head of state even more independent from other authorities and strengthens its position in the political system ${ }^{27}$. Besides, it gives the President the right to refer to the will of his voters, ensuring "the durability of political leadership and the stability of a given system" 28 .

The President of the Republic of Poland is a very specific institution in the Polish political system not only because of the original model of the presidency but also because a lot depends on the preferred style of exercising power. The style of the presidency "determines whether the President involves in resolving conflicts or chooses a passive attitude or - in the worst case - makes presidency a contradiction of the constitutional institution"29. The elements of the presidency style include legal and extra-legal factors, such as the totality of constitutional and statutory standards defining the position and tasks of the head of state, skills, personality, the socio-political situation ${ }^{30}$, and discourse ${ }^{31}$. There are two most general styles of the presidency: passive and active. The first of these occurs when the head of state only exercises his constitutional powers. In the second one, the President additionally inspires various actions for the benefit of the state and society, joins conflicts as a mediator, tries to alleviate anxieties, and counteract manipulations ${ }^{32}$. The chosen

27 B. Dziemidok-Olszewska, op. cit., p. 145.

28 L. Sobkowiak, Legitymacja polityczna, [in:] A. W. Jabłoński, L. Sobkowiak (eds.), Studia z teorii polityki, vol. 2, Wrocław 1998, p. 155.

29 A. Suska, Prezydent Rzeczypospolitej Polskiej..., p. 84.

30 T. Słomka, Style prezydentury. Analiza porównawcza, «Przegląd Sejmowy» 2005, iss. 6, p. 46.

31 The discourses of the Polish Presidents is a relatively new analytical area with high research potential. See more: A. Suska, Prezydent Rzeczypospolitej Polskiej..., pp. 101-129; A. Suska, Siła stów u szczytu władzy. Porównanie przemówień inaugurujacych prezydentury Lecha Kaczyńskiego i Andrzeja Dudy, «Społeczeństwo i Polityka» 2019, no. 4, pp. 211-229.

32 T. Słomka, Prezydent Rzeczypospolitej po 1989 roku. Ujęcie porównawcze, Warsaw 2005, p. 214. 
style has a high impact on the behavior of the head of state in case of a constitutional crisis or constitutional rot, the will to use constitutional and statutory powers, authority, and the selection of methods to alleviate the situation. It is worth mentioning that research ${ }^{33}$ emphasize that $^{2}$ in a conflict between state institutions, as well as in severe national and international challenges, personal qualities and style of exercising power gain importance.

\section{Constitutional crisis and the President's possible actions}

The constitutional powers of the President of the Republic of Poland regarding monitoring the constitutional order can be divided into five categories: organizational and procedural, initiating, inhibiting, control, and extraordinary ${ }^{34}$. Some of them may prevent constitutional crises or create opportunities to solve them.

According to art. 118 para. 1 and art. 144 para. 3 pt 4 of the Constitution of The Republic of Poland, the head of state has the right of legislative initiative without restrictions on the scope of the proposed act. The only exceptions are legislative initiatives concerning the Budget, an interim budget, amendments to the Budget, a statute on the contracting of public debt, as well as a statute granting financial guarantees by the State, which belong exclusively to the Council of Ministers (art. 221). Researchers note that presidential legislative initiatives should cover key issues for the state, be associated with the constitutional role of this institution, and avoid infringing on the competencies explicitly granted in the Constitution to the Council of Ministers, especially if it could destabilize the government's policy ${ }^{35}$. By taking the legislative initiative, the President fulfills the assumptions of the active presidency model and contributes to the process of passing new laws. This constitutional right is of the greatest importance in counteracting the parliamentary crisis, destabilization of the constitutional order, and the ineffectiveness of the political system's mechanisms.

33 K. Skarżyńska, Prezydent na trudne czasy: analiza psychologiczno-spoteczna, «Studia Politologiczne» 2016, vol. 42, pp. 132-133.

34 A. Suska, Prezydent Rzeczypospolitej Polskiej..., pp. 33-69.

35 P. Sarnecki, Prezydent Rzeczypospolitej Polskiej: komentarz do przepisów, Kraków 2000, p. 83; A. Rakowska, Prerogatywy prezydenta $w$ Konstytucji RP z 2 kwietnia 1997 r., [in:] T. Mołdawa, J. Szymanek (eds.), Instytucja prezydenta. Zagadnienia teorii i praktyki na tle doświadczeń polskich oraz wybranych państw obcych, Warsaw 2010, p. 76. 
The right to submit a bill to amend the Constitution (art. 235 para. 1) may at first seem controversial - due to the President's role as the guardian of the Constitution. However, in this way, the head of state has the opportunity to adapt its content to changing political, economic, and social conditions. Besides, this right can counteract situations where a provision arouses great criticism, social tensions, and also disturbs the constitutional order, and contributes to the formation of a systemic practice unfavorable for the state.

The President always participates in the last stage of the legislative process and has the right to make one of three decisions: to sign a bill (art. 122 para. 2), to refer it to the Constitutional Tribunal for an adjudication upon its conformity to the Constitution (art. 122 para. 3), or to veto it, which means referring the bill with a motivated request to the Sejm for its reconsideration (art. 122 para. 5). It is not permitted to veto and to refer to the Constitutional Tribunal in connection with the same act. The authors of the Constitution of the Republic of Poland concluded that such a right would be "inconsistent with the president's function as an arbitrator and moderator (...). [and] could delay the work of parliament" 36 . The choice between the three possibilities is left to the discretion of the head of state.

Any doubts related to the constitutionality of the bill can be the premise authorizing the head of state to refer to the Constitutional Tribunal. This doubt may result from the content contradiction (material unconstitutionality), incompatibility with the applicable legislation while passing the act, or passing it by an authority that does not have the competence to do $\mathrm{so}^{37}$. The President may be motivated to veto a bill by various factors - constitutional, political, economic, financial, social, moral, as well as any errors of a formal, linguistic, editorial, or substantive nature. The requirement of written justification allows the Sejm and the public opinion to know them. This means that vetoing is not only a technical act but allows every side to present and exchange their arguments ${ }^{38}$, which is very important in a conflict between the President and the Sejm.

36 A. Więckowska, Weto Prezydenta Rzeczypospolitej Polskiej w praktyce politycznej po wejściu $w$ życie nowej konstytucji, «Przegląd Sejmowy» 2003, no. 6, p. 35.

37 R. Balicki, Udział Prezydenta Rzeczypospolitej Polskiej w postępowaniu ustawodawczym, Wrocław 2001, p. 119.

38 P. Zakrzewski, Kompetencje prezydenta o charakterze hamujacym $w$ procesie ustawodawczym (na przykładzie polskich rozwiazań ustrojowych), [in:] T. Mołdawa, J. Szymanek (eds.), Instytucja prezydenta. Zagadnienia teorii i praktyki na tle doświadczeń polskich oraz wybranych państw obcych, Warsaw 2010, p. 100. 
The group of controlling powers makes it possible to intervene when a constitutional crisis occurs due to the fault of a specific person or institution. President has a right to apply to the Sejm to bring a member of the Council of Ministers to responsibility before the Tribunal of State (art. 144 para. 3 pt 13, art. 156 para. 2). The basis for this may be both a violation of the Constitution or a bill and the commission of an offense connected with the duties of the office (art. 156 para. 1). Although this decision clearly undermines the authority of the government and the prime minister, the President, as the guardian of the constitutional order, has the full right, and even the obligation, to strive to remove from the office a person who does not respect the rules of the constitutional order. The final decision, regarding whether or not to prosecute, belongs to the Sejm, which adopts a relevant resolution by a $3 / 5$ majority of the statutory number of deputies (art. 156 para. 2).

The Constitution provided the President with a wide range of applications to the Constitutional Tribunal. In addition to the previously described right to refer the bill before signing for an adjudication upon its conformity to the Constitution, the head of state can apply for an ex-post control of the act (article 188 pt 1), and also to examine: the conformity of statutes and international agreements to the Constitution (art. $188 \mathrm{pt}$ 1), the conformity of a statute to ratified international agreements whose ratification required prior consent granted by statute (art. 188 pt 2), the conformity of legal provisions issued by central State organs to the Constitution, ratified international agreements and statutes (art. 188 pt 3) and the conformity to the Constitution of the purposes or activities of political parties (art. 188 pt 4). Additionally, the head of state may apply for a resolution of a dispute over authority between central constitutional organs (art. 189, 192).

The last controlling power of the President is requesting the Supreme Chamber of Control to carry out an audit (article 144 para. 3 pt 10). It opens up many possibilities for the head of state in the scope of implementing the protection of the constitutional order and counteracting crises. The control in itself is not a sanction but can be an introduction to the further actions aimed at eliminating the identified deficiencies primarily those related to the violation of constitutional provisions or values.

The head of state can mitigate disputes and ensure harmony in the political system through presidential political arbitration too. It may happen in a more formalized way, such as, for example, delivering a Message to the Sejm, the Senate or the National Assembly (art. 140), conven- 
ing the Cabinet Council ${ }^{39}$ to discuss matters important for the state (art. 141), or ordering a nationwide referendum with the consent of the Senate (art. 125) to obtain the opinion of the public on specific topics and monitor the changes taking place therein. As a part of the arbitration, the President may also take non-formal actions. As the guardian of the Constitution and authority among the public, as well as one of the most recognizable persons in the state ${ }^{40}$, the head of state has the best opportunities to spread knowledge about the Constitution and the law. Thanks to official speeches, comments, and actions, the President can informally activate social groups, express approval of their ideas or moderate the antagonisms and conflicts ${ }^{41}$, which is consistent with the assumptions of the active presidency model and prevents processes leading to constitutional crises.

\section{Conclusions}

Constitutional crises and constitutional rot pose a threat to the existence and integrity of liberal democracy as well as the constitutional order. Some factors can cause them, such as the presence of defective legal solutions, malevolence, and dishonesty of authorities, practices that violate the law and serve specific persons or groups of interest.

Results from the study indicate that the President is a significant part of the Polish political system, the importance of which grows in crises and disharmony of the constitutional order. The head of state should represent high moral values and has a wide range of powers to prevent emergencies, moderate them, and reduce their negative impact. However, it is impossible to describe the role of the President in crises by taking into consideration only the constitutional competencies because the preferred style of the presidency has a vast impact on the effects of the President's intervention. A head of state who prefers a passive style, subordinate to the party line, or the influence of certain social groups, will never be an efficient political arbitrator or a person able to prevent a constitutional crisis due to serious deficiencies in credibility and authority. Only a conciliatory President: a good listener, open to different opinions, surrounded by experts, ready to discuss and make

39 The head of state presides over the Council of Ministers, but the Cabinet Council does not possess its competencies and cannot make binding decisions.

40 A. Suska, Prezydent Rzeczypospolitej Polskiej..., p. 22.

41 Ibidem, p. 75. 
concessions, but at the same time independent and able to make a point, if the common good and the state's interest require, will be able to moderate the crisis in a way to ensure the best possible solution.

\section{Bibliography}

Balicki R., Udziat Prezydenta Rzeczypospolitej Polskiej w postępowaniu ustawodawczym, Wrocław 2001.

Balkin J. M., Constitutional Crisis and Constitutional Rot, «Maryland Law Review» 2017, vol. 77 , iss. 1 .

Banaszak B., Prawo konstytucyjne, Warsaw 2010.

Cern K. M., Jak rozumieć rolę konstytucji we wspótczesnym społeczeństwie demokratycznym?, «Studia prawno-ekonomiczne» 2016, vol. CI.

Collier P., Rohner D., Democracy, Development, and Conflict, «Journal of the European Economic Association» 2008, vol. 6, iss. 2-3.

Cooper G., The Origin of Financial Crises. Central Banks, Credit Bubbles and the Efficient Market Fallacy, New York 2010.

Dahrendorf R., Out of Utopia: Toward a Reorientation of Sociological Analysis, «American Journal of Sociology»1958, vol. 64, no. 2

Dziemidok-Olszewska B., Instytucja prezydenta w państwach Europy Środkowo-Wschodniej, Lublin 2003.

Garlicki L., Polskie prawo konstytucyjne. Zarys wykładu, Warsaw 2011.

Glaeser E., DiPasquale D., The Los Angeles Riot and the Economics of Urban Unrest, «Journal of Urban Economics» 1998, vol. 43, iss. 1.

Griffin S. M., Broken Trust. Dysfunctional Government and Constitutional Reform, Lawrence 2015.

Kuciński J., Ustrój konstytucyjny Rzeczypospolitej Polskiej, Warsaw 2015.

Levinson S., Balkin J. M., Constitutional Crises, «University of Pennsylvania Law Review» 2009, vol. 157, iss. 3.

Maranini G., Il mito della Constituzione, Roma 1996.

McClelland Ch. A., The Acute International Crisis, «World Politics» 1961, vol. 14, iss. 1.

Mucha J., Konflikt $i$ społeczeństwo: z problematyki konfliktu społecznego we wspótczesnych teoriach zachodnich, Warsaw 1978.

Piotrowski R., Społeczeństwo obywatelskie w świetle Traktatu z Lizbony, [in:] M. Szyszkowska, S. Maciejewski (ed.), Polska bez Polskiego Czerwonego Krzyża?!, Warsaw 2011.

Rakowska A., Prerogatywy prezydenta $w$ Konstytucji RP z 2 kwietnia 1997 r., [in:] T. Mołdawa, J. Szymanek (eds.), Instytucja prezydenta. Zagadnienia teorii i praktyki na tle doświadczeń polskich oraz wybranych państw obcych, Warsaw 2010.

Ratajczak M., Narracje o kryzysie: przyczyny kryzysu, [in:] B. Cymbrowski, P. Tomczok (eds.), Ekonomie $w$ literaturze $i$ kulturze, Katowice 2017.

Robinson J. A., Crisis, [in:] D. L. Sills (ed.), International Encyclopedia of the Social Sciences, vol. 3, New York 1968.

Skarżyńska K., Prezydent na trudne czasy: analiza psychologiczno-społeczna, «Studia Politologiczne» 2016, vol. 42.

Skuczyński P., Pojęcie kryzysu $w$ filozofii i naukach społecznych a kryzysy prawne, «Filozofia Publiczna i Edukacja Demokratyczna» 2018, vol. 7, iss. 1. 
Słomka T., Prezydent Rzeczypospolitej po 1989 roku. Ujęcie porównawcze, Warsaw 2005.

Słomka T., Stan demokracji konstytucyjnej $w$ Polsce na tle modelu transformacji systemowej, [in:] T. Słomka (ed.), Demokracja konstytucyjna w Polsce, Warsaw 2019.

Słomka T., Style prezydentury. Analiza porównawcza, «Przegląd Sejmowy» 2005, iss. 6.

Sobkowiak L., Legitymacja polityczna, [in:] A. W. Jabłoński, L. Sobkowiak (eds.), Studia z teorii polityki, vol. 2, Wrocław 1998.

Suska A., Prezydent Rzeczypospolitej Polskiej jako organ czuwajacy nad przestrzeganiem porządku konstytucyjnego, Toruń 2019.

Suska A., Siła słów u szczytu władzy. Porównanie przemówień inaugurujących prezydentury Lecha Kaczyńskiego i Andrzeja Dudy, «Społeczeństwo i Polityka» 2019, no. 4.

Szymanek J., Elementy racjonalizacji $w$ konstrukcji parlamentarnego systemu rządów: analiza rozwiazań zawartych w Konstytucji RP, [in:] T. Mołdawa, J. Szymanek, M. Mistygacz (eds.), Parlamentarny system rzadów. Teoria i praktyka, Warsaw 2012.

Talmon J. L., The Origins of Totalitarian Democracy, London 1952.

Tushnet M. V., Constitutional Hardball, «The John Marshall Law Review» 2004, vol. 37.

Vincent K. S., Benjamin Constant and Constitutionalism, «Historia Constitucional» 2015, no. 16.

Whittington K. E., Yet Another Constitutional Crisis?, «William \& Mary Law Review» 2002, vol. 43 , iss. 5 .

Więckowska A., Weto Prezydenta Rzeczypospolitej Polskiej w praktyce politycznej po wejściu $w$ życie nowej konstytucji, «Przegląd Sejmowy» 2003, no. 6.

Zakrzewski P., Kompetencje prezydenta o charakterze hamujacym $w$ procesie ustawodawczym (na przykładzie polskich rozwiazań ustrojowych), [in:] T. Mołdawa, J. Szymanek (eds.), Instytucja prezydenta. Zagadnienia teorii $i$ praktyki na tle doświadczeń polskich oraz wybranych państw obcych, Warsaw 2010. 